\title{
Wnt signaling in granulosa cell tumors of the ovary
}

\author{
Brian Kilonzo, MD, ${ }^{1}$ Traci Neff, BA, ${ }^{1}$ Megan I. Samuelson, MD, ${ }^{2}$ Michael J. Goodheart, \\ $\mathrm{MD}^{1}$
}

Keywords: Granulosa cell tumor, ovarian neoplasms, Wnt signaling

\section{Background}

Granulosa cell tumors (GCT), a malignant type of sex-cord stromal tumor, account for approximately $2-5 \%$ of all ovarian malignancies. They are often identified before they have spread beyond the ovary, but advanced disease can be quite challenging to treat. Wht signaling has been suggested to contribute to the formation of GCT. We hypothesized Wnt signaling was involved in human GCT.

\section{Methods}

We examined a total of 12 samples for both RNA and protein expression in human GCT using qualitative real-time PCR (qPCR) and immunohistochemical (IHC) staining, respectively, to determine the presence of Wnt signaling.

\section{Results}

Both RNA and protein levels of $B$ catenin and Lef-1 were elevated in GCT compared to non-cancerous ovarian controls.

\section{Conclusions}

Wnt signaling appears to be activated in ovarian GCT, and may pose as a potential therapeutic target. Continued research is needed to uncover the role of Wnt signaling in this rare tumor type.

Presented at "Practical Update in Ob/Gyn," the University of lowa Obstetrics and Gynecology Postgraduate conference, 24 October 2014, hotelVetro \& Conference Center, lowa City, lowa 52240.

${ }^{1}$ Department of Obstetrics and Gynecology, Carver College of Medicine, University of lowa Hospitals and Clinics, lowa City, IA, 52242

${ }^{2}$ Department of Pathology, University of lowa Hospitals and Clinics, lowa City, lowa 52242

Please cite this abstract as: Kilonzo B, Neff T, Samuelson MI, Goodheart MJ. Wnt signaling in granulosa cell tumors of the ovary. Proc Obstet Gynecol. 2013;4(3):Article 14 [ 1 p.]. Available from: http://ir.uiowa.edu/pog/ . Free full text article.

Corresponding author: Brian Kilonzo, Department of Obstetrics and Gynecology, University of lowa, 200 Hawkins Drive, lowa City, IA 42242, brian-kilonzo@uiowa.edu

Copyright: (c) 2014 Kilonzo, et al. This is an open-access article distributed under the terms of the Creative Commons Attribution License, which permits unrestricted use, distribution, and reproduction in any medium, provided the original author and source are credited. 